\title{
Heterogenic institutional investors and their influence on corporate innovation: Evidence from a transition economy
}

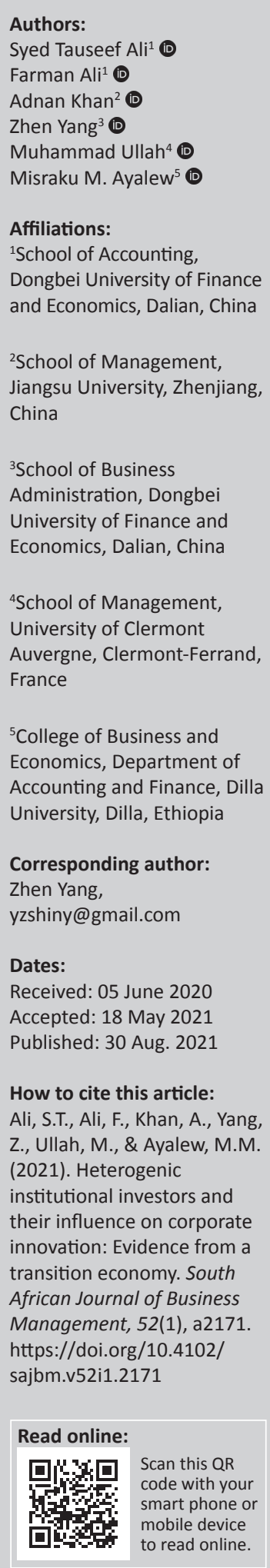

Purpose: The literature lacks a specific mechanism that may help to explain the variation in corporate innovation. This research helps to explain a specific mechanism that affects corporate innovation.

Design/methodology/approach: Ordinary Least Square (OLS) regression has been used to analyse the data collected from Chinese manufacturing firms listed on Shenzhen and Shanghai Stock Exchanges from 2007 to 2015. Innovation input has been measured through research and development (R\&D) expense scaled by total assets, while the number of forward invention patent citations has been used to measure the quality of innovation performance.

Findings/results: The results show that pressure-resistance institutional investors (PR institutions) encourage, while pressure-sensitive institutional investors (PS institutions) discourage R\&D intensity. Additionally, exploring the efficiency logic, results show that PR institutions positively moderate both in SOEs (state-owned enterprises) and non-SOEs, while in contrast, PS institutions negatively moderate only in non-SOEs. Overall, the results support our argument that institutional investors' business relations act as a mechanism that affects not only their fiduciary responsibilities, but also their proneness to pressure which in turn affects corporate innovation.

Practical implications: There is a great need to protect institutional investors from forming business relations with firms in which they invest. This strategy will help institutional investors to perform their valuable role in enhancing corporate innovation.

Originality/value: The article contributes to the existing literature by highlighting institutional investors' heterogenic behaviour. Second, this research highlights institutional investors' business relations, which affect R\&D intensity and innovation performance.

Keywords: corporate innovation; pressure-sensitive institutional investors; pressureresistance institutional investors; R\&D intensity; institutional investors; China.

\section{Introduction}

Innovation is a very significant corporate decision, and firms invest a large amount of resources to be successful in innovation (Ucar, 2018). The literature on corporate innovation highlights many factors that affect corporate innovation. Financial literature shows that institutional ownership is a key variable that affects a manager's decisions regarding innovation and risktaking (Aghion, Van Reenen, \& Zingales, 2013; Baysinger, Kosnik, \& Turk, 1991). Usually, managers avoid innovations because of uncertainty, capital intensity, long-term nature, and stochastic reasons - things going wrong purely as a result of some other random occurrences (Unsal \& Rayfield, 2019). To overcome this phenomenon, institutional investors are viewed as an effective external corporate governance mechanism having the capabilities to enhance corporate innovation (Chang, Liang, \& Wang, 2019; Choi, Lee, \& Williams, 2011; Xu, Wang, \& Cheng, 2015). However, the influence of institutional investors on innovation is a mix, full of contradictions and they vary because of their types (Aghion 2013; Bushee, 1998), roles (Kochhar \& David, 1996), and heterogeneous characteristics (Brickley, Lease, \& Smith, 1988). The literature however, lacks a specific mechanism through which how institutional investors can affect research and development (R\&D) intensity and innovation performance can be highlighted.

The previous literature is unclear and indecisive in highlighting the channel through which the institutional investors may affect corporate innovation. Aghion et al. (2013) highlight that the career

Copyright: (C) 2021. The Authors. Licensee: AOSIS. This work is licensed under the Creative Commons Attribution License. 
concern model - where institutional owners increase innovation incentives through reducing career risks - is the effective primary mechanism that safeguards managers from innovation's stochastic factors. Contrarily, Berger, Stocker and Zeileis (2017) argue that the career concern model heavily depends on the model framework and claim that by using the count data hurdle model for analysis, neither the career concern model nor lazy managers' hypothesis - managers prefer a quiet life and institutional investors force them to innovate - satisfactorily explain the mechanism. Therefore, to know the channel through which institutional investors affect corporate innovation, there is a strong need to carefully examine the impact of institutional investors on corporate innovation using the same categorisation of institutional investors as used by Brickley et al. (1988) and David, Kochhar and Levitas (1998). This study, therefore, has two basic aims to explore. Firstly, this study intends to investigate the influence of pressure-resistance (PR) and pressure-sensitive (PS) institutions on $R \& D$ intensity and corporate innovation in state-owned enterprises (SOEs) - a legal entity created by a government to partake in commercial activities on the government's behalf, either wholly or partially owned by a government - and non-SOEs in China. Secondly, the study explores how PR institutional investors (PR institutions) and PS institutional investors (PS institutions) differ in affecting the association between innovation input ( $R \& D$ intensity) and innovation output (corporate innovation).

This study uses a unique dataset of Chinese institutional investors from 2007 to 2015, Chinese manufacturing firms listed as A-shares on the Shenzhen Stock Exchange and Shanghai Stock Exchange. We found that PR institutions have a positive, while PS institutions have a negative impact on R\&D intensity. These findings show that because of the absence of PR institutions' business relations, they focus more on the long-term perspective than the short-term perspective; this is why firms invest more in innovative projects. Further, the study reveals that PR institutions have a positive impact on R\&D intensity only in SOEs. By contrast, PS institutions have a negative impact on R\&D intensity only in non-SOEs. Additionally, we found that PR institutions strongly influence innovation performance as compared to PS institutions. We also found that PR institutions positively moderate the association between $R \& D$ intensity and innovation performance both in SOEs and non-SOEs. These results show the importance of PR institutions, and highlight their significance in both the SOEs and non-SOEs. Furthermore, PS institutions negatively moderate the associations between the R\&D intensity and innovation performance only in non-SOEs.

This research contributes to the existing literature in many ways. Firstly, this research has a methodological contribution. Both the studies of Brickley et al. (1988) and David et al. (1998) used cross-sectional data. However, the nature of cross-sectional data specifically for innovation in the study of Kochhar and David (1996) left a wider gap for improvement. More importantly, Brickley et al. (1988) used homogenous institutional categorisation to study their impact on voting for anti-takeover amendments, while Kochhar and David (1996) used the same categorisation for corporate innovation (measured through new product development). Our study is the first that uses the heterogenic categorisation of institutional investors based on their disparate behaviour derived from their business relations. Furthermore, this study uses more robust methods to measure corporate innovation through forward invention patents citation, which is much better than new product development used by Kochhar and David (1996) earlier in their research to measure corporate innovation. So, these are the business relations of institutional investors with the factor firms which make them different from each other (i.e. heterogenous from each other) and make these institutions behave differently with different firms.

Secondly, categorising the institutions into PR and PS institutional investors provides new insights towards R\&D intensity. Our study confirms the myopic investor hypothesis viewpoint for the first time by having this unique institutional categorisation, which complements the results of Graves (1988), who identified that institutional investors (in general) have a negative effect on innovation (R\&D intensity). Our study is consistent with Graves (1988) research by finding that only PS institutional investor has a negative impact on R\&D intensity, while in contrast, PR institutions have a positive impact on R\&D intensity. This study strengthens the viewpoint that PS institutions do foster short-term orientation and are sensitive to short-term gains instead of long-term gains through corporate innovation.

Thirdly, as discussed earlier that not only ownership structure (Rong, Wu, \& Boeing, 2017), rather the role of institutional investors (Chi, Liao, \& Yang, 2019) also differs in China. More specifically, there is a lack of empirical evidence regarding these heterogenic institutions and their impact on corporate innovation in SOEs and non-SOEs. We fill this gap by finding that PR institutions only have a positive impact on $R \& D$ intensity in SOEs, while they have no effect in non-SOEs. On the other hand, PS institutions have a negative influence on R\&D intensity only in non-SOEs, and have no impact on SOEs. Moreover, we also investigated the influence of institutional investors on corporate innovation performance in SOEs and non-SOEs.

Finally, this study deals with the efficiency logic which refers to firms' capabilities to utilise their own resources with full potential. We highlight that institutional investors have heterogenous characteristics; therefore, institutional investors differ in their capabilities to affect the efficient utilisation of research funds which in turn affects corporate innovation.

\section{Theoretical framework and hypothesis development}

When institutional investors are dissatisfied with a firm's performance, they do not coerce the board to fire managers because most of the time, they do not have adequate representation on the board to do so (Aghion et al., 2013). 
However, institutions can pressurise boards to take action on their behalf and take corrective measures to safeguard their interests. This is only possible if institutional investors have the capacity and competence to pressurise boards, and it is only possible if institutions do not depend on the investing firms for their own business operations (Brickley et al., 1988). Business relations and institutional investors' dependence on their investing firms affect their fiduciary responsibilities, which is why these institutions can be categorised into heterogenic groups based on their business relations and proneness to pressures (Brickley et al., 1988). These categorisations of institutions into PR, PS, and pressure-indifferent institutions (Brickley et al., 1988; Kochhar \& David, 1996) also help identify which institutions act as monitors with long-term interests and which institutions act myopic by acquiring short-term benefits. Similarly, pointing towards the efficiency logics, PR institutional investors can act as monitors and fabricate strategies that may enhance resource utilisation, utilisation of research, and development funds in specific, to enhance innovation output.

\section{Hypothesis development}

\section{Pressure-sensitive institutions and research and development intensity}

Despite institutions' business relations, other elements affect the association between institutions and corporate innovation. One of those factors is the lack of firm-specific information in less developed economies (Ebrahimnejad \& Hoseinzade, 2019), making it hard to evaluate the true longterm significance of that company (Porter, 1992). Institutional investors' capabilities are limited to monitoring each firm in their portfolios' capabilities and monitoring each firm in their portfolios (Ward, Yin, \& Zeng, 2020). Therefore, institutions use information related to firm performance and current corporate earning that is easily accessible. However, this information loses sight of long-term performance and does not possess long-term innovation and competitiveness. In this uncertain situation, institutional investors, specifically PS institutions, behave like arbitragers and turn their portfolios frequently to capitalise on short-term gains rather than long-term. Therefore, managers cut $R \& D$ expenditure to boost short-term earnings and keep institutions satisfied at the cost of long-term corporate performance, innovation, and competitiveness (Bushee, 1998, 2001; Rong et al., 2017). Therefore we hypothesise that:

H1: There is a negative relationship between PS institutional investors and R\&D intensity.

\section{Pressure-resistance institutional investors and research and development intensity}

Some specific types of institutional investors are more helpful for R\&D investments. Institutions such as long-term-oriented institutions are considered more aligned with the corporate innovation's timeframe and help encourage R\&D. However, the mechanism through which institutions affect innovation varies. The quite-life hypothesis suggests that managers try to avoid innovation (Bertrand \& Mullainathan, 2003), but institutional investors encourage managers to innovate
(Aghion et al., 2013). On the other hand, a prominent viewpoint highlights another mechanism of the careerconcern hypothesis. This viewpoint suggests that institutions safeguard managers against stochastic reasons behind innovation and the risk of being fired from their jobs as a result of adverse consequences if innovation ventures fail (Aghion et al., 2013). This is why institutions, especially PR institutions that are free from business dependence (Brickley et al., 1988), safeguard managers from career risks and encourage them to finance innovative ventures. Therefore, we hypothesise that:

H2: There is a positive relationship between PR institutional investors and R\&D intensity.

\section{Pressure-resistance versus pressure-sensitive institutional investors and innovation performance}

Some of the institutional investors have a business relationship with the companies in which they invest. This helps to generate an economic activity that affects the operating income of institutions. The ability of institutions to affect firms' decisions in which they invest heavily rests on their dependence on a business relationship (Brickley et al., 1988). Pressure-resistance institutions do not depend on firms in which they hold equity to survive their business operations (Kochhar \& David, 1996). This is the reason that PR institutions perform their fiduciary responsibility better than other institutions and pressurise management to safeguard their interests in firms, and try to gear activities towards long-term perspectives such as corporate innovation.

On the other hand, PS institutions have ongoing business relations with the factor corporations to acquire economic benefits to smoothen their business operations (Brickley et al., 1988). Therefore, the influence that these institutions can exert on a firm's board and management deriving from the power of ownership are refuted by their dependence on business relations (Finkelstein, 1992). Hence, these institutions having such business relations hesitate to questions or influence executive action. This is why if these institutions try to raise their voice against the myopic managerial activities, they are threatened for the withdrawal of the business on which these institutions depend. Therefore, this dependence makes these PS institutions more prone to risk, making these institutions unable to influence managers to pursue long-term, risky and innovative projects. Therefore we hypothesise that:

H3: PR institutional investors are more positively related to innovation performance than PS institutional investors.

\section{The moderating role of pressure-resistance institutions on the association between research and development intensity and innovation performance}

Pressures-resistance institutional investors not only induce pressures on the board as a result of the absence of business relations, instead, they also ensure that they are fully updated because of the significant stakes in the corporations in order to perform timely informed decisions. If the financial institutions prefer to invest in those firms that favour short- 
term gains, consequently, these institutions underestimate the expected gains in the long run (Jensen, 1988). This is the reason that rational stakeholders evaluate their investments in a particular firm based on entirely accessible public information (Gibbons, Iliev, \& Kalodimos, 2020). Therefore, these institutions value those expenditures, which are mandatory to enhance corporate value in the long run. Most of the time, shareholders having significant holdings in the equity thus weighing their investments with more care, and therefore they can make optimum investment decisions (Aoki, 1984). Hence, the key to successful investment evaluation and optimum portfolio selection is based on accessible public information. This is the reason that institutional investors possess more knowledge regarding the market as compared to individual investors. Therefore, the PR institutions having no business relations with the firms in which they invest are better positioned to pressurise the board and managers to optimally utilise the available resources favouring long-term gains through innovative projects in light of this information.

The large proportions of equity holdings by the PR institutions serve as a trap for these institutions. These two conditions of significant shareholding and the absence of PR institutions' business relations threaten these institutions about the two possible scenarios (Kochhar \& David, 1996). First, these PR institutions cannot sell their equity in large blocks because it may lead to a considerable loss in stock prices, making this option unpleasant (Aoki, 1984). Second, let us assume that these PR institutions are capable of trading their stocks in the stock market through some means; even then, they may face difficulties in finding new avenues for investments because of the well-diversified portfolios of institutions (Gilson \& Kraakman, 1991). These two factors of potential loss in equity market prices and deficiency of feasible future ventures, along with the ability to pressurise the boards, set the ground for PR institutions to actively monitor the boards and management for long-term gains through innovative ventures:

H4: PR institutional investors positively moderate the relationship between R\&D intensity and innovation output.

\section{The moderating role of pressure-sensitive institutional investors on the association between research and development intensity and innovation performance}

In fact, initiating an R\&D project depends on two things: its impact on a company's long-term profitability and its visibility and acceptance in the market (Rong et al., 2017). Therefore, continuous pressure from the market compels short-termism managers to select such ventures that are more observable to financiers (Ferreira, Manso, \& Silva, 2014). Therefore, managers may try to relinquish R\&D ventures and pursue more conservative and visible projects (Rong et al., 2017). This kind of short-termism by managers is further aggravated by speculative institutional investors, which show little interest in firms' long-term performance (Rong et al., 2017), such as PS institutions. This kind of situation is well documented by (Bushee, 1998, 2001), those institutions which focus on short-term gain can compel managers to waive innovative projects for the sake of high short-term performance. Therefore, we hypothesise that:

H5: PS institutional investors negatively moderate the relationship between R\&D intensity and innovation output.

\section{Methods Sample and data}

To test the hypothesis, we collected data from Chinese manufacturing firms listed as A-shares on the Shenzhen Stock Exchange and Shanghai Stock Exchange. We chose 2007 as the initial study year because China Securities Regulatory Commission (CSRC) mandated listed companies since 2007 to reveal detailed information related to changes in equity and ownership. Moreover, new accounting rules for listed firms were also introduced in 2007. On the other hand, we terminated our data in 2016 to overcome the problem of citation truncation (there are fewer citations for later patents, normally citations need 5 years of a window to observe them) because the citation of a patent typically peak within 5 years since it is granted (Fleming \& Sorenson, 2001; He \& Tian, 2013).

We concentrated only on listed manufacturing firms because firms in manufacturing industries are assumed to be more dynamic than firms from other industries, and provide more opportunities for each firm to compete through successful products and technology breakthroughs (Piperopoulos, Wu, \& Wang, 2018). Moreover, to collect data for corporate innovation, we referred to the SIPO of China database because it offers comprehensive information concerning the patent's data. Simultaneously, the data related to innovation intensity (R\&D expense), firm performance, and corporate governance was collected from the China Stock Market \& Accounting Research (CSMAR) Database. Data related to institutional ownership was collected from the Wind Financial Database (Bromiley \& Washburn, 2011; Jiang \& Yuan, 2018). We also obtained data on financial performance and corporate governance for each company from the CSMAR Database.

\section{Variables}

\section{Dependent variables}

Innovation input: We measured the innovation input by $R \& D$ expense (scaled by total assets) in a given year. $R \& D$ expense has been considered a critical form of creativity and innovation efforts that can serve as a useful proxy for innovation input in an organisation (Greve, 2003).

Innovation performance: Patents have three subcategories: utility model patents, design patents, and invention patents (Chi et al., 2019). In previous studies like Griliches (1981), the number of patents was used to measure the quantity (i.e. speed) of R\&D activities rather than the quality of innovation output (Chang et al., 2019). Therefore, we used the number of forward invention patent citations to measure the quality of innovation, excluding self-citation for each year (Rong et al., 2017; Wagner \& Wakeman, 2016; Zhong, 2018), which 
captures the technical and market value of the patents of each firm (Wagner \& Wakeman, 2016).

\section{Independent variables}

Pressure-sensitive institutional ownership: Consistent with prior research, PS institutional investors are influenced by the firms they invest in and had fewer chances to interfere in corporate decisions (Brickley et al., 1988; Rong et al., 2017). These institutional investors included insurance funds, securities companies, trust companies, banks, and financial companies that have an association with companies. To measure the pressure-sensitive institutional ownership, we sum up the proportion of shares held by these pressuresensitive institutions.

Pressure-resistant institutional ownership: Following the study of Kochhar and David (1996), PR institutional investors had neglectable relation with the factor corporation, so these kinds of investors may play an efficient role in corporate governance and innovation decision. Social security funds, securities investment funds, and qualified foreign institutional investors (QFII) were regarded as PR institutional investors. Furthermore, we measure the institutional ownership at different ownership levels, such as at least $0 \%, 1 \%$, and $5 \%$ (as blocker holder) of a firm's equity. Figure 1 illustrates the conceptual diagram to better understand the variables and hypothesis of the study.

\section{Control variables}

This study used a diverse range of control variables, which may influence innovation performance. The control variables include:

- Firm size was measured by the natural log of the firm's asset (Cherkasova \& Kurlyanova, 2019; Chi et al., 2019). Generally, large firms possess more resources (financial, skilled works, innovation expertise, and marketing skills) than small firms.

- Firm age was measured by the number of years since its incorporation (Medase \& Barasa, 2019)

- Leverage was measured by total liability divided by total assets at the end of the year (Ali, Yang, Sarwar, \& Ali, 2019; Su, Xiao, \& Yu, 2018).

- Growth was calculated as the firm's sale growth rate (Chi et al., 2019).

- State Ownership was measured as a dummy variable equal to 1 if the company is a SOE, and is 0 otherwise (Chi et al., 2019; Ndiaye, Razak, Nagayev, \& Ng, 2018).

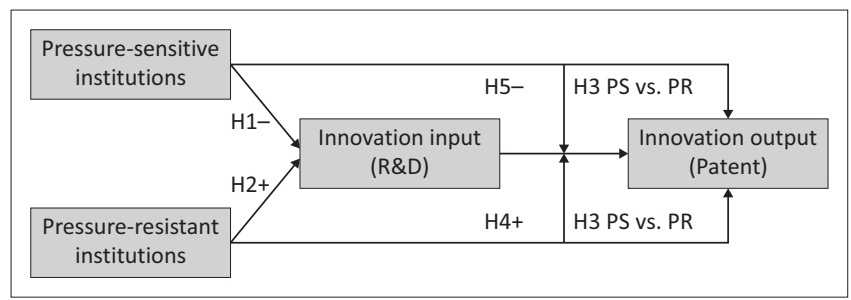

$R \& D$, research and development; PR, pressure-resistant; PS, pressure-sensitive FIGURE 1: Conceptual framework.
- Profitability was measured by the net income divided by total assets (Song, Ai, \& Li, 2015).

- Industry competition (Herfindahl-Hirschman Index [HHI]) was measured by the sum of squares of the percentages of sales of the focal firm in each industry based on 3-digit Standard Industrial Classification (SIC) (Zhou, Gao, \& Zhao, 2017).

- $R E D$ intensity is operationalised as the ratio of $R \& D$ expenses to sales (Feng \& Johansson, 2018; Yang, Ali, Ali, Sarwar, \& Khan, 2020).

- Property, plant, and equipment (PPE) also affect the innovation output because firms with more resources have extra capability to invest more in R\&D projects and innovate more, which affects innovation output and innovation quality as well. Therefore, PPE was taken as a control variable measured as total fixed assets divided by the total assets.

We also included industry dummy variables and year dummy variables in our regression to control industry and time fixed effects (Chang et al., 2019; Ding, Jia, Wu, \& Zhang, 2014). The main variables are described in Table 1.

\section{Estimation method}

To test our hypothesis, we employed Ordinary Least Square (OLS) regressions in a fixed-effect model. The Hausman Specification Test was performed, and on the basis of its

TABLE 1: Variables and data sources.

\begin{tabular}{|c|c|c|}
\hline Variables & Description & Sources \\
\hline Innovation input & $\begin{array}{l}\text { Research and development expense } \\
\text { scaled by total assets }\end{array}$ & CSMAR \\
\hline $\begin{array}{l}\text { Innovation } \\
\text { performance }\end{array}$ & $\begin{array}{l}\text { The number of forward invention } \\
\text { patent citations a firm has received } \\
\text { in natural logarithmic form }\end{array}$ & SIPO, China \\
\hline $\begin{array}{l}\text { PR institutions } \\
(N, \%)\end{array}$ & $\begin{array}{l}\text { PR institutional ownership, public } \\
\text { pension funds, mutual funds, and } \\
\text { endowments and foundations } \\
\text { (owning at least } N \text { percent of a firm's } \\
\text { equity, } N=0,1,5 \text { ) }\end{array}$ & $\begin{array}{l}\text { Calculated from annual } \\
\text { reports of the listed } \\
\text { companies and website } \\
\text { of institutional investors }\end{array}$ \\
\hline $\begin{array}{l}\text { PS Institutions } \\
(N, \%)\end{array}$ & $\begin{array}{l}\text { PS institutional ownership, insurance } \\
\text { companies, banks, and nonbank trusts } \\
\text { (owning at least } N \text { percent of a firm's } \\
\text { equity, } N=0,1,5 \text { ) }\end{array}$ & $\begin{array}{l}\text { Calculated from annual } \\
\text { reports of the listed } \\
\text { companies and website } \\
\text { of institutional investors }\end{array}$ \\
\hline Firm size & $\begin{array}{l}\text { The natural logarithm of the total } \\
\text { number of employees }\end{array}$ & CSMAR \\
\hline Firm age & $\begin{array}{l}\text { The firm's founding year subtracted } \\
\text { from the observation year }\end{array}$ & CSMAR \\
\hline Leverage & Total debt over total assets & CSMAR \\
\hline Profitability & The net margin of equity (ROE) & CSMAR \\
\hline Growth & Increase the rate of operating revenue & CSMAR \\
\hline PPE & $\begin{array}{l}\text { The net value of fixed assets over total } \\
\text { assets }\end{array}$ & CSMAR \\
\hline Board Size & $\begin{array}{l}\text { The natural logarithm of the number } \\
\text { of directors in the boardroom }\end{array}$ & CSMAR \\
\hline SOE & $\begin{array}{l}\text { The dummy variables equal to } 1 \text { if the } \\
\text { company is a SOE and is } 0 \text { otherwise }\end{array}$ & CSMAR \\
\hline $\mathrm{HHI}$ & $\begin{array}{l}\text { The Herfindahl index to measure } \\
\text { industrial competition }\end{array}$ & CSMAR \\
\hline $\begin{array}{l}\text { Market } \\
\text { development }\end{array}$ & NERI index on market development & NERI index database \\
\hline
\end{tabular}

Note: This table reports the names of variables included in this study along with the measurement techniques and data sources. Innovation input illustrates R\&D intensity. Pressure-resistance institution is an independent variable and illustrates PR institutional investors. Pressure-sensitive institution is also an independent variable and illustrates PS institutional investors.

CSMAR, China Stock Market \& Accounting Research; SIPO, State Intellectual Property Office; $\mathrm{PR}$, pressure-resistant; PS, pressure-sensitive; PPE, Property, plant, and equipment; SOE, state-owned enterprises; HHI, Herfindahl-Hirschman Index; NERI, The National Economic Research Institute; ROE, Return on Equity. 


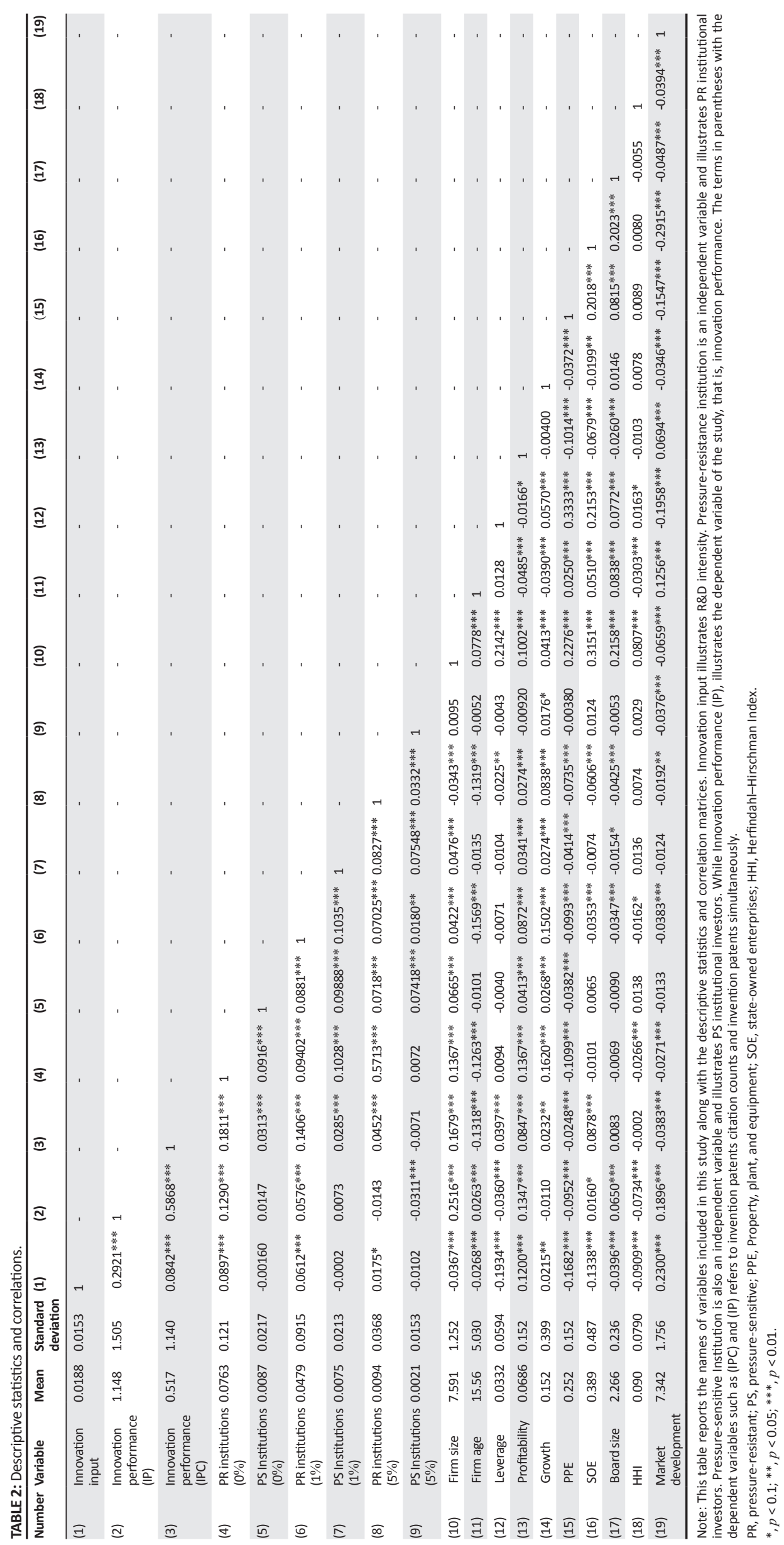


results, it was decided that the Fixed-Effect Model is appropriate. To overcome the possible simultaneity bias, all the independent variables have been lagged by 1 year, excluding the dummy variables (Piperopoulos et al., 2018). Following Rong et al. (2017), we used the log of one plus invention citation counts as the exploratory variables. Specifically, to overcome possible endogeneity produced by unobserved variables, we used year fixed-effect and industry fixed-effect in our models.

\section{Results}

\section{Main results}

Table 2 presents the correlation analysis and descriptive statistics for the variables. The table shows that all the correlations are reasonably low. These correlation coefficients suggest that multicollinearity is not a cause of serious concern. We also mean-centre the variables before generating those interaction terms, except for dummy variables, to alleviate the problem of multicollinearity.

Table 3 presents the regression of $R \& D$ intensity using a sample from 2007 to 2015. In this analysis, we have used three samples to see independent variables' influence across different samples. In Table 3, there are three models: model (1) comprises both the independent variables (PR institutions and PS institutions) and control variables for the entire sample (including both kinds of enterprises SOEs and nonSOEs). While model (2) investigates the effects of the same variables in a sample consisted of only SOEs and, model (3) is based on only non-SOEs.

Table 3, model (1) comprises the main continuous explanatory variables (PR and PS institutions) and control variables. Pressure-sensitive institutional investors' coefficient is negative and significant at a 1\% level of significance, thus lending support to $\mathrm{H} 1$ that predicts a negative relationship between PS institutional investors and R\&D intensity. Nonetheless, PR institutional investors' coefficient is positive and significant, lending support to $\mathrm{H} 2$, which predicts a positive relationship between PR institutional investors and R\&D intensity.

In model (2), the coefficients PR institutions are positive and significant at a $1 \%$ level of significance, which predicts that PR institutional investors are more positively related to R\&D intensity in SOEs than non-SOEs. In model (3), PS institutional investors' coefficient is negative and significant at a 5\% level of significance, which predicts that PS institutional investors are more negatively related to $R \& D$ intensity in non-SOEs than SOEs.

Table 4 presents the regression of innovation performance using a sample from 2007 to 2015. In this analysis, we have used three samples to see the influence of independent variables across these different samples.

In models $1-3$, PR institutional investors' coefficient having less than $1 \%$ ownership is positive and significant at a $1 \%$ level. However, the PS institutional investors having the same ownership of less than $1 \%$ is also positive but insignificant, thus lending support to $\mathrm{H} 3$ which, predicts that PR institutional investors are more positively related to innovation performance than PS institutional investors.

In models 4-6, PR institutional investors' coefficient, this time having at least $1 \%$ ownership, is positive and significant at $1 \%$ level. While the PS institutional investors having the same ownership of at least $1 \%$ is positive and insignificant, this predicts that PR institutional investors are more positively related to innovation performance than PS institutional

TABLE 3: The institutional investors and innovation input (research and development intensity).

\begin{tabular}{|c|c|c|c|c|c|c|}
\hline \multirow[t]{2}{*}{ Models } & \multicolumn{2}{|c|}{ (1) } & \multicolumn{2}{|c|}{ (2) } & \multicolumn{2}{|c|}{ (3) } \\
\hline & Full sample & Statistics & SOE sample & Statistics & Non-SOE sample & Statistics \\
\hline Pressure-resistance ownership (at least $1 \%$ ) & $0.0022 *$ & 1.67 & $0.0074 * * *$ & 2.91 & 0.0003 & 0.19 \\
\hline Pressure-sensitive ownership (at least $1 \%$ ) & $-0.0156 * * *$ & -2.73 & -0.0122 & -1.19 & $-0.0154^{* *}$ & -0.982 .29 \\
\hline Firm size & $0.0004 * *$ & 2.18 & $0.0009 * *$ & 2.57 & 0.0003 & 0.98 \\
\hline Firm age & $0.0010^{* * *}$ & 9.70 & $0.0015^{* * *}$ & 9.25 & $0.0004 * * *$ & 3.11 \\
\hline Leverage & $-0.0067 * *$ & -2.36 & -0.0017 & -0.42 & $-0.0109 * * *$ & -2.71 \\
\hline Profitability & $0.0013 *$ & 1.72 & $0.0023 *$ & 1.88 & 0.0009 & 0.87 \\
\hline Growth & $0.0006 * *$ & 2.22 & 0.0007 & 1.49 & $0.0011 * * *$ & 2.91 \\
\hline PPE & -0.0012 & -0.83 & -0.0003 & -0.14 & -0.0003 & -0.18 \\
\hline Board size & -0.0000 & -0.07 & -0.0010 & -0.87 & 0.0007 & 0.82 \\
\hline SOE & 0.0004 & 0.39 & - & - & - & - \\
\hline $\mathrm{HHI}$ & $0.0105^{* * *}$ & 2.85 & 0.0087 & 1.15 & 0.0059 & 1.44 \\
\hline Market development & 0.0001 & 0.16 & 0.0001 & 0.15 & 0.0005 & 1.07 \\
\hline Constants & 0.0004 & 0.06 & -0.0037 & -0.66 & 0.0108 & 1.32 \\
\hline Industry dummies & Yes & - & Yes & - & Yes & - \\
\hline Firm fixed effect & Yes & - & Yes & - & Yes & - \\
\hline$N$ & 8670 & - & 3272 & - & 5398 & - \\
\hline$F$ & 26.7332 & - & 24.6757 & - & 10.1860 & - \\
\hline$R^{2}$ & 0.1150 & - & 0.1863 & - & 0.0717 & - \\
\hline
\end{tabular}

PPE, Property, plant, and equipment; SOE, state-owned enterprises; HHI, Herfindahl-Hirschman Index.

$*, p<0.10 ; * *, p<0.05 ; * *, p<0.01$. 


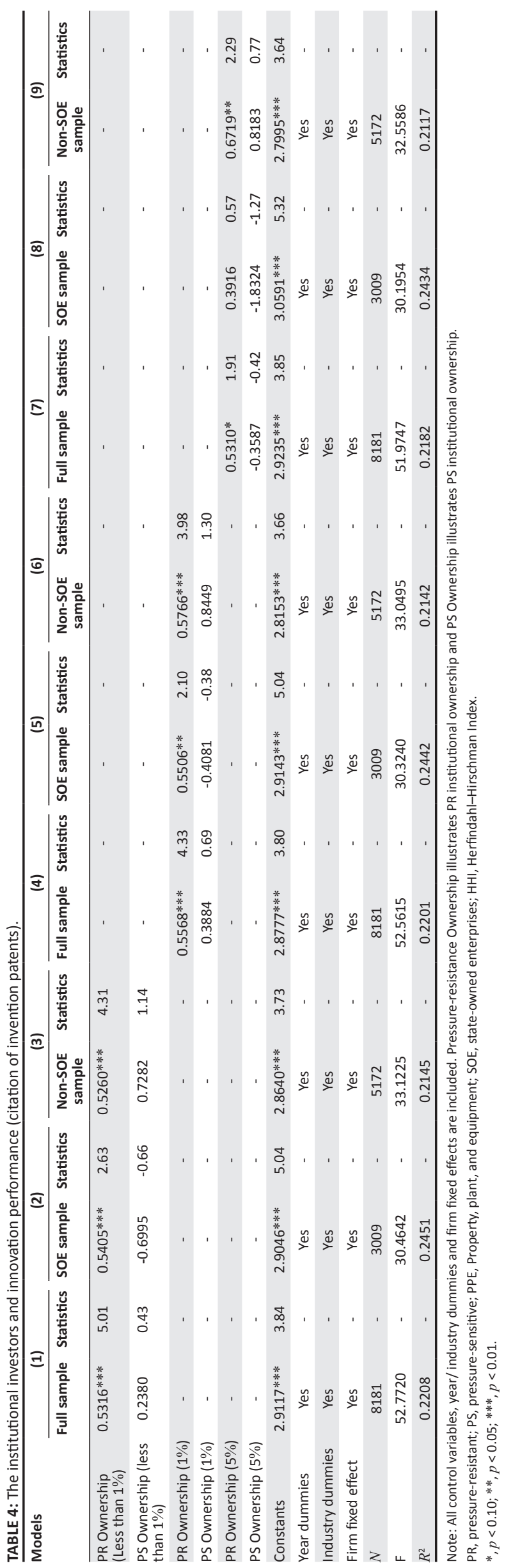




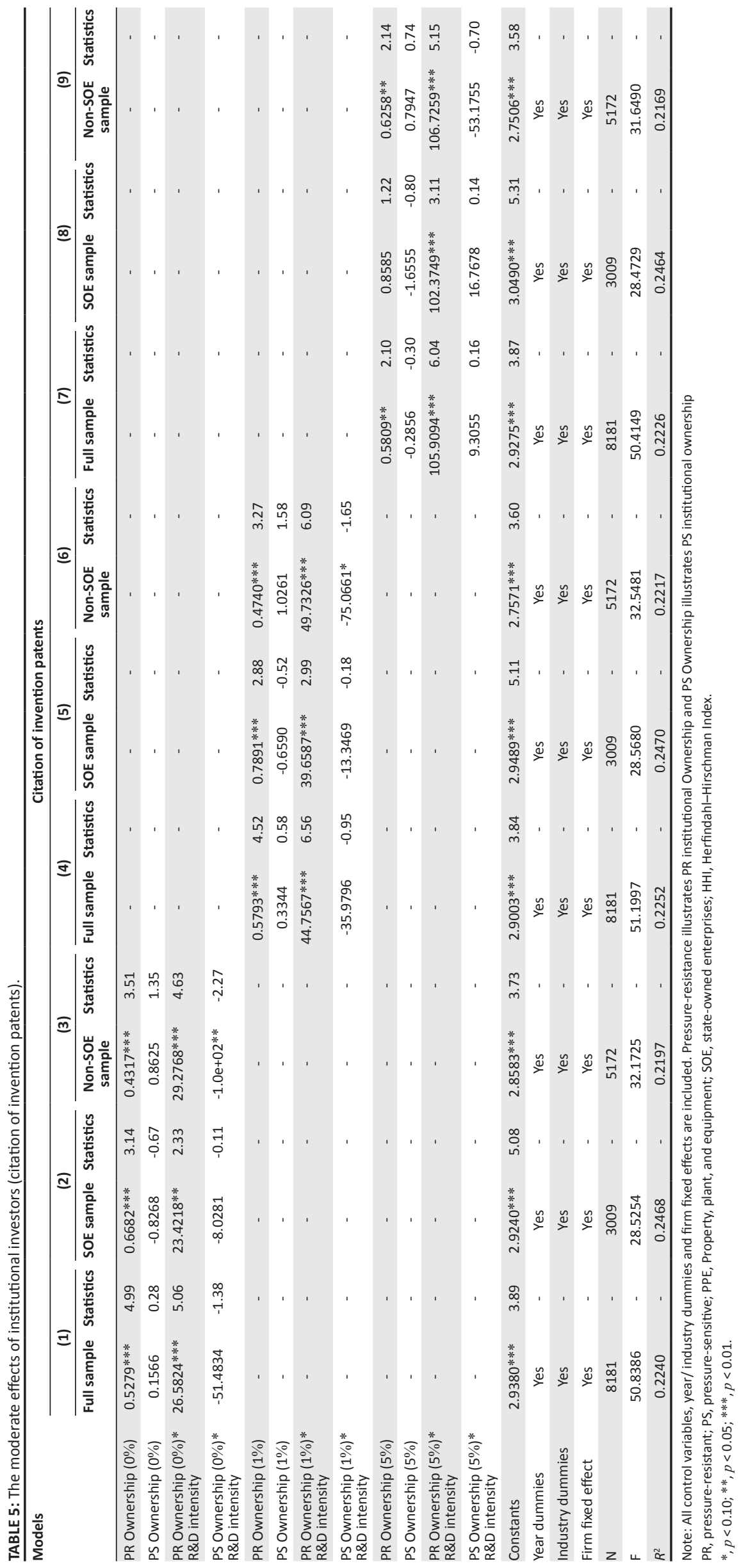


TABLE 6: The influence of institution investors (dummy variables) on research and development intensity.

\begin{tabular}{|c|c|c|c|c|c|c|}
\hline \multirow[t]{3}{*}{ Models } & \multicolumn{6}{|c|}{ R\&D intensity } \\
\hline & \multicolumn{2}{|c|}{ (1) } & \multicolumn{2}{|c|}{ (2) } & \multicolumn{2}{|c|}{ (3) } \\
\hline & Full sample & Statistics & SOE sample & Statistics & Non-SOE sample & Statistics \\
\hline Dummy_PR Ownership (at least 1\%) & $0.0005^{* *}$ & 2.16 & 0.0007 & 1.52 & $0.0006 * *$ & 2.02 \\
\hline Dummy_PS Ownership (at least $1 \%$ ) & $-0.0007 * * *$ & -2.77 & -0.0003 & -0.70 & $-0.0010 * * *$ & -3.02 \\
\hline Constants & 0.0005 & 0.08 & -0.0024 & -0.43 & 0.0106 & 1.30 \\
\hline Year dummies & Yes & - & Yes & - & Yes & - \\
\hline Industry dummies & Yes & - & Yes & - & Yes & - \\
\hline Firm fixed effect & Yes & - & Yes & - & Yes & - \\
\hline$N$ & 8670 & - & 3272 & - & 5398 & - \\
\hline $\mathrm{F}$ & 26.7855 & - & 24.3345 & - & 10.4072 & - \\
\hline$R^{2}$ & 0.1152 & - & 0.1842 & - & 0.0732 & - \\
\hline
\end{tabular}

Note: All control variables, year/ industry dummies and firm fixed effects are included. Pressure-resistance Ownership illustrates PR institutional ownership and PS Ownership illustrates PS institutional ownership.

PR, pressure-resistant; PS, pressure-sensitive; PPE, Property, plant, and equipment; SOE, state-owned enterprises; HHI, Herfindahl-Hirschman Index.

$*, p<0.10 ; * *, p<0.05 ; * * *, p<0.01$.

investors. Categorising the sample into full (comprises of both SOEs and non-SOEs), SOEs and non-SOEs, also predicts that PR institutions are more positively related to innovation performance irrespective of sample selection. In other words, we can also interpret the results that PR institutions have a positive and significant impact on innovation performance irrespective of sample selection.

Table 5 presents PR and PS institutions' moderation effects on the relationship between R\&D intensity and innovation performance. The sample categorisation and ownership of exploratory variables are just the same as in Table 4.

In model 1-3, the coefficient of the interaction term, Pressure res ownership $(0 \%) * R \mathcal{E} D$ intensity is positive and significant at $1 \%$ level, at every category of sample selection (full, SOEs and non-SOEs), thus lending support to $\mathrm{H} 4$, which predicts that PR institutional investors positively moderates the relationship between $R \& D$ intensity and innovation performance. The interaction term's coefficient, Pressure_sens ownership $(0 \%) * R \mathcal{E D}$ intensity, is negative and significant at a $5 \%$ level of significance. Thus it lends its support to H5, which predicts that PS institutional investors negatively moderate the relationship between $R \& D$ intensity and innovation performance.

The preceding models, 4-6 and 7-9, also present the same results for PR and PS institutions' moderating role. We can interpret the results that PR institutions positively moderates the association between the R\&D intensity and innovation performance irrespective of the ownership size (less than $1 \%$, at least $1 \%$, and at least $5 \%$ ) and sample selection (full, SOEs and non-SOEs). While PS institution negatively moderates the association between R\&D intensity and innovation performance only in non-SOEs, and their level of significant decrease as the ownership size increases from less than $1 \%$ to $5 \%$ ownership.

\section{Robust check}

Firstly, following the prior literature, we used institutional investors' dummies (Dummy_Pressure_res ownership and
Dummy_Pressure_sens ownership), and the value was equal to 1 if the PR and PS institutions have at least 1\% ownership, otherwise zero. The dependent variable was $R \& D$ intensity. Results in Table 6 present that our findings are still robust though we used an alternative measure to represent institutional ownership.

Secondly, once again, we used dummies of institutional investors and the value was equal to 1 if institutional ownership was equal to less than $1 \%$, at least $1 \%$ and at least $5 \%$, respectively, otherwise zero. Results from Table 7 reveal that our findings are still robust, meaning that PR institutions have a pronounced positive effect on innovation performance than PS institutions, although we used an alternative measure as a proxy to represent financial institution's ownership.

\section{Discussion and conclusion}

This study intended to investigate the association between heterogenic institutional investors and corporate innovation, and highlighted the mechanism through which institutional investors affect the managerial actions that, in turn, affect corporate innovation. Berger et al. (2017) argued that the career concern model heavily depends on the model framework and claim that count data hurdle model, ${ }^{1}$ neither the career concern model nor lazy managers hypothesis, satisfactorily explains the mechanism at work. Therefore, there is a great need to clarify the mechanism through which institutional investors affect corporate innovation.

Therefore, this study used a unique dataset of Chinese institutional investors from 2007 to 2015 of manufacturing firms listed on the Shenzhen Stock Exchange and Shanghai Stock Exchange. We found that PR institutions have a positive impact on R\&D intensity, while PS institutions have a negative impact on R\&D intensity. However, when we analysed the sample concerning SOEs and non-SOEs, then we found that PR institutions have a positive impact on R\&D intensity only in SOEs, while they have no impact on non-SOEs. On the other hand, PS institutions have a negative impact on R\&D intensity only in non-SOEs, while they have no impact in

1.'Hurdle models are two-part models with a binary part that models the decision to innovate at all, and a count part that models ongoing innovation, respectively'. 


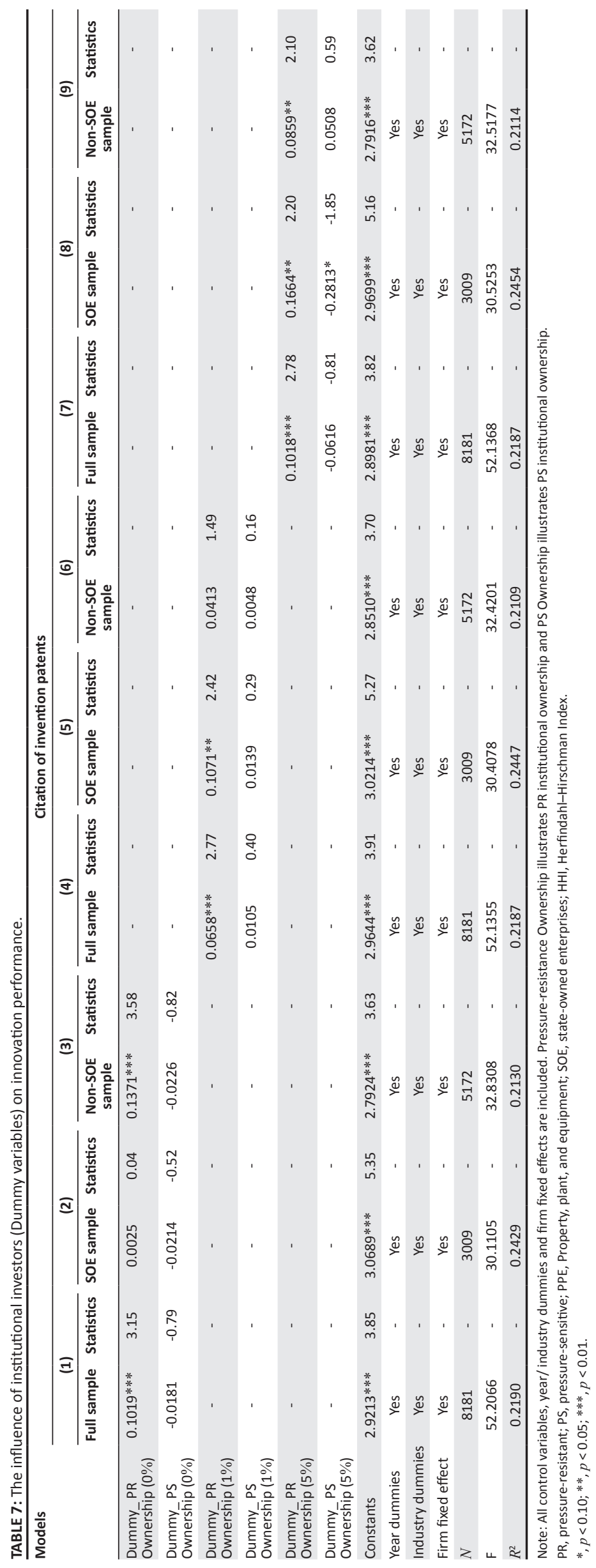


SOEs. Furthermore, we found that PR institutions are more positively associated with innovation performance than PS institutions. Additionally, we found that PR institutions positively moderate the association between R\&D intensity and innovation performance both in SOEs and non-SOEs. While PS institutions negatively moderate the associations between the R\&D intensity and innovation performance only in non-SOEs.

\section{Practical implications}

This research has numerous practical implications from a public policy standpoint. The prevalent conviction that institutions have a negative impact on corporate innovation (Porter, 1992), was negated by the study of (Kochhar \& David, 1996). Nonetheless, our study using a heterogenic categorisation of PR institutions and PS institutions complement the study of Porter, by arguing that PS institutions have a negative impact on R\&D intensity. In fact, our study highlighted the mechanism of business relations that affects institutional investors and resultantly corporate innovation.

Conspicuous investors such as Warren Buffet once endorsed a need to tax the institutional investors on gains provided that the stocks are held for less than 1 year to influence long-term investments (Lowenstein, 1988). However, in light of this study, we argue that there is no need for this kind of policy to influence long-term investments. Rather, there is a need to review the proxy guidelines and other regulations that help prevent institutions from affecting managers (Black, 1992).

\section{Limitations and future research directions}

This study has certain limitations that require careful consideration while interpreting the results. Firstly, this study is established on data from a single country. Although China is one of the most prominent transition economies, the ownership structure is entirely composite in China (Zhou et al., 2017). A transition economy, or in other words, the transitional economy, refers to an economy that changes from central planning to a market economy (Feige, 1994). Therefore, these findings cannot be generalised to other developed economies. Furthermore, cross-country analysis is required to increase the understanding of this phenomenon. Secondly, our investigation is confined to manufacturing industrylisted companies, and we have determined that industries vary in their regulations and standards. Thus, cross-industrial investigations are warranted to determine whether these outcomes are extendable to other industries or not.

\section{Acknowledgements}

We thank the valuable comments of the editor in chief Prof. M. de Klerk and two anonymous reviewers.

\section{Competing interests}

No conflict of interest exists in the submission of this manuscript, and all authors approve the manuscript for publication. I would like to declare on behalf of my co-authors that the work described was original research that has not been published previously, and not under consideration for publication elsewhere, in whole or in part. All the authors listed have approved the manuscript that is enclosed.

\section{Authors' contributions}

S.T.A. was responsible for writing. Z.Y. was responsible for formal analysis, methodology, writing and correspondence. F.A. was responsible for writing, revision, editing the manuscripts. M.U., M.M.A. and A.K. revised and edited the manuscript.

\section{Ethical considerations}

This article followed all the ethical guidelines for a research project without direct contact with human or animal subjects.

\section{Funding information}

This research was supported by the Research Foundation of School of Business Administration of Dongbei University of Finance and Economics, China (Grand number: GSY2021006).

\section{Data availability}

The datasets generated and/or analysed during the current study are not publicly available and are hand collected; but are available from the corresponding author on reasonable request.

\section{Disclaimer}

The views and opinions expressed in this article are those of the authors and do not necessarily reflect the official policy or position of any affiliated agency of the authors.

\section{References}

Aghion, P., Van Reenen, J., \& Zingales, L. (2013). Innovation and institutional ownership. American Economic Review, 103(1), 277-304. https://doi. org/10.1257/aer.103.1.277

Ali, S.T., Yang, Z., Sarwar, Z., \& Ali, F. (2019). The impact of corporate governance on the cost of equity: Evidence from cement sector of Pakistan. Asian Journal of Accounting Research, 4(2), 293-314. https://doi.org/10.1108/AJAR-08-2019-0062

Allen, F. (1993). Stock Markets and Resource Allocation. In C. Mayer \& X. Vives (Eds.), Capital Markets and Financial Intermediation (pp. 81-108). Cambridge University Press: Cambridge.

Aoki, M. (1984). The co-operative game theory of the firm. Oxford: Oxford university press.

Audia, P.G., \& Greve, H.R. (2006). Less likely to fail: Low performance, firm size, and factory expansion in the shipbuilding industry. Management Science, 52(1), 83-94. https://doi.org/10.1287/mnsc.1050.0446

Ayyagari, M., Demirgüç-Kunt, A., \& Maksimovic, V. (2011). Firm innovation in emerging markets: The role of finance, governance, and competition. Journal of Financial
and Quantitative Analysis, 46(6), 1545-1580. https://doi.org/10.1017/ and Quantitative

Baysinger, B.D., Kosnik, R.D., \& Turk, T.A. (1991). Effects of board and ownership structure on corporate R\&D strategy. Academy of Management Journal, 34(1), 205-214. https://doi.org/10.5465/256308

Berger, S., Stocker, H., \& Zeileis, A. (2017). Innovation and institutional ownership revisited: An empirical investigation with count data models. Empirical Economics, 52(4), 1675-1688. https://doi.org/10.1007/s00181-016-1118-0

Bertrand, M., \& Mullainathan, S. (2003). Enjoying the quiet life? Corporate governance and managerial preferences. Journal of Political Economy, 111(5), 1043-1075. https://doi.org/10.1086/376950

Black, B.S. (1992). Agents watching agents: The promise of financial intermediary voice. UCLA Law Review, 39(4), 811-893. 
Brickley, J.A., Lease, R.C., \& Smith, Jr. C.W. (1988). Ownership structure and voting on antitakeover amendments. Journal of Financial Economics, 20, 267-291. https:// antitakeover amendments. Journal of Fin
doi.org/10.1016/0304-405X(88)90047-5

Bromiley, P., \& Washburn, M. (2011). Cost reduction vs. innovative search in R\&D. Journal of Strategy and Management 4(3), 196-214. https://doi. org/10.1108/17554251111152243

Buchanan, J. (1972). Toward analysis of close behavioral systems. In J. Buchanan \& R.D. Tollison (Eds.), Theory of public choice? Political applications of economics (pp. 11-23). Ann Arbor, MI: University of Michigan Press.

Bushee, B.J. (1998). The influence of institutional investors on myopic R\&D investment behavior. Accounting Review 73(3), 305-333.

Bushee, B.J. (2001). Do institutional investors prefer near-term earnings over long-run value? Contemporary Accounting Research, 18(2), 207-246. https://doi. org/10.1506/J4GU-BHWH-8HME-LEOX

Camisón-Zornoza, C., Lapiedra-Alcamí, R., Segarra-Ciprés, M., \& Boronat-Navarro, M. (2004). A meta-analysis of innovation and organizational size. Organization Studies, 25(3), 331-361. https://doi.org/10.1177/0170840604040039

Chang, H.Y., Liang, W.-I., \& Wang, Y. (2019). Do institutional investors still encourage patent-based innovation after the tech bubble period? Journal of Empirical Finance, 51, 149-164. https://doi.org/10.1016/j.jempfin.2019.02.003

Cherkasova, V., \& Kurlyanova, A. (2019). Does corporate R\&D investment support to decrease of default probability of Asian firms? Borsa Istanbul Review, 19(4), 344-356. https://doi.org/10.1016/j.bir.2019.07.009

Chi, J., Liao, J., \& Yang, J. (2019). Institutional stock ownership and firm innovation: Evidence from China. Journal of Multinational Financial Management, 50, 44-57.

Choi, S.B., Lee, S.H., \& Williams, C. (2011). Ownership and firm innovation in a transition economy: Evidence from China. Research Policy, 40(3), 441-452. https://doi.org/10.1016/j.respol.2011.01.004

Czarnitzki, D., \& Kraft, K. (2004). An empirical test of the asymmetric models on innovative activity: Who invests more into $R \& D$, the incumbent or the challenger? Journal of Economic Behavior \& Organization, 54(2), 153-173. https://doi. org/10.1016/j.jebo.2003.01.008

David, P., Kochhar, R., \& Levitas, E. (1998). The effect of institutional investors on the level and mix of CEO compensation. Academy of Management Journal, 41(2), 200-208. https://doi.org/10.5465/257102

Ding, S., Jia, C., Wu, Z., \& Zhang, X. (2014). Executive political connections and firm performance: Comparative evidence from privately-controlled and state-owned enterprises. International Review of Financial Analysis, 36, 153-167. https://doi. enterprises. International Review
org/10.1016/j.irfa.2013.12.006

Ebrahimnejad, A., \& Hoseinzade, S. (2019). Short-sale constraints and stock price informativeness. Global Finance Journal, 40, 28-34. https://doi.org/10.1016/j. gfj.2018.11.002

Feige, E.L. (1994). The transition to a market economy in Russia: Property rights, mass privatization and stabilization. In G.S. Alexander \& G. Skąpska (Eds.), A fourth way? Privatization, property, and the emergence of new market economics (pp. 57-78). New York, NY: Routledge.

Feng, X., \& Johansson, A.C. (2018). Living through the Great Chinese Famine: Early-life experiences and managerial decisions. Journal of Corporate Finance, 48, 638-657. https://doi.org/10.1016/j.jcorpfin.2017.11.012

Ferreira, D., Manso, G., \& Silva, A.C. (2014). Incentives to innovate and the decision to go public or private. The Review of Financial Studies, 27(1), 256-300. https://doi. org/10.1093/rfs/hhs070

Finkelstein, S. (1992). Power in top management teams: Dimensions, measurement and validation. Academy of Management Journal, 35(3), 505-538. https://doi. org $/ 10.2307 / 256485$

Fleming, L., \& Sorenson, O. (2001). Technology as a complex adaptive system: Evidence from patent data. Research Policy, 30(7), 1019-1039. https://doi. org/10.1016/S0048-7333(00)00135-9

Gibbons, B., Iliev, P., \& Kalodimos, J. (2020). Analyst information acquisition via EDGAR. Management Science, 67(2), 769-793. https://doi.org/10.1287/ mnsc.2019.3465

Gilson, R.J., \& Kraakman, R. (1991). Reinventing the outside director: An agenda for institutional investors. Stanford Law Review, 43(4), 863-906. https://doi. org/10.2307/1228922

Graves, S.B. (1988). Institutional ownership and corporate R\&D in the compute industry. Academy of Management Journal, 31(2), 417-428. https://doi. org $/ 10.2307 / 256557$

Greve, H.R. (2003). A behavioral theory of R\&D expenditures and innovations: Evidence from shipbuilding. Academy of Management Journal, 46(6), 685-702 https://doi.org/10.5465/30040661

Griliches, Z. (1981). Market value, R\&D, and patents. Economics Letters, 7(2), 183-187. https://doi.org/10.1016/0165-1765(87)90114-5

Guo, B., Pérez-Castrillo, D., \& Toldrà-Simats, A. (2019). Firms' innovation strategy under the shadow of analyst coverage. Journal of Financial Economics, 131(2) 456-483. https://doi.org/10.1016/j.jfineco.2018.08.005

He, J.J., \& Tian, X. (2013). The dark side of analyst coverage: The case of innovation Journal of Financial Economics, 109(3), 856-878. https://doi.org/10.1016/j. jineco.2013.04.001
Holmstrom, B. (1982). Managerial incentive schemes - A dynamic perspective. In C.G. Aminoff (Eds.), Essays in econolrfics and management in honour of Lars Wahlbeck (pp. 169-182). Svenska handelshögskolan: Helsinki.

Jarrell, G., \& Lehn, H. (1985). Institutional ownership, tender offers, and long-term investments. Washington, DC: Office of the Chief Economist, Exchange Commission.

Jensen, M.C. (1988). The takeover controversy: Analysis and evidence. In J.C. Coffee, L. Lowenstein, \& S. Rose Ackerman (Eds.), Knights, raiders and targets (pp. 314-354). Oxford: Oxford University Press.

Jiang, X., \& Yuan, Q. (2018). Institutional investors' corporate site visits and corporate innovation. Journal of Corporate Finance, 48, 148-168. https://doi.org/10.1016/j. jcorpfin.2017.09.019

Kochhar, R., \& David, P. (1996). Institutional investors and firm innovation: A test of competing hypotheses. Strategic Management Journal, 17(1), 73-84. https://doi. org/10.1002/(SICI)1097-0266(199601)17:1\%3C73::AID-SMJ795\%3E3.0.CO;2-N

Lowenstein, L. (1988). What's wrong with Wall Street: Short-term gain and the absentee shareholder. New York, NY: Addison Wesley Publishing Company.

Medase, K., \& Barasa, L. (2019). Absorptive capacity, marketing capabilities, and innovation commercialisation in Nigeria. European Journal of Innovation Management, 22(5), 790-820. https://doi.org/10.1108/EJIM-09-2018-0194

Ndiaye, N., Razak, L.A., Nagayev, R., \& Ng, A. (2018). Demystifying small and medium enterprise's (SMEs) performance in emerging https://doi.org/10.1016/j. bir.2018.04.003 and developing economies. Borsa Istanbul Review, 18(4), 269-281.

Niskanen, W.A. (1971). Bureaucracy and representative government. New Brunswick, NJ: Transaction Publishers.

Pfeffer, J. (1973). Size, composition, and function of hospital boards of directors: A study of organization-environment linkage. Administrative Science Quarterly, 18(3), 349-364. https://doi.org/10.2307/2391668

Piperopoulos, P., Wu, J., \& Wang, C. (2018). Outward FDI, location choices and innovation performance of emerging market enterprises. Research Policy, 47(1), 232-240. https://doi.org/10.1016/j.respol.2017.11.001

Porter, M.E. (1992). Capital disadvantage: America's failing capital investment system. Harvard Business Review, 70(5), 65-82.

Rong, Z., Wu, X., \& Boeing, P. (2017). The effect of institutional ownership on firm innovation: Evidence from Chinese listed firms. Research Policy, 46(9), 1533-1551. https://doi.org/10.1016/j.respol.2017.05.013

Shleifer, A., \& Vishny, R.W. (1986). Large shareholders and corporate control. Journal of Political Economy, 94(3 Part 1), 461-488. https://doi.org/10.1086/261385

Shleifer, A., \& Vishny, R.W. (1994). Politicians and firms. The Quarterly Journal of Economics, 109(4), 995-1025. https://doi.org/10.2307/2118354

Song, M., Ai, H., \& Li, X. (2015). Political connections, financing constraints, and the optimization of innovation efficiency among China's private enterprises. Technological Forecasting and Social Change, 92, 290-299. https://doi. org/10.1016/j.techfore.2014.10.003

Su, Z.-Q., Xiao, Z., \& Yu, L. (2018). Do political connections enhance or impede corporate innovation? International Review of Economics \& Finance, 63, 94-110. https://doi.org/10.1016/j.iref.2018.08.012

Ucar, E. (2018). Local creative culture and corporate innovation. Journal of Business Research, 91, 60-70. https://doi.org/10.1016/j.jbusres.2018.05.040

Unsal, O., \& Rayfield, B. (2019). Institutional investors and medical innovation. The Quarterly Review of Economics and Finance, 74, 190-205. https://doi. org/10.1016/j.qref.2019.01.013

Van de Ven, A.H. (1986). Central problems in the management of innovation. Management science, 32(5), 590-607. https://doi.org/10.1287/mnsc.32.5.590

Wagner, S., \& Wakeman, S. (2016). What do patent-based measures tell us about product commercialization? Evidence from the pharmaceutical industry. Research Policy, 45(5), 1091-1102. https://doi.org/10.1016/j.respol.2016.02.006

Ward, C., Yin, C., \& Zeng, Y. (2020). Motivated monitoring by institutional investors and firm investment efficiency. European Financial Management, 26(2), 348-385. https://doi.org/10.1111/eufm.12232

Xu, X., Wang, C., \& Cheng, S. (2015). Myopic investor or active monitor? The role of institutional investors in corporate innovation. International Journal of Financial Research, 6(2), 23. https://doi.org/10.5430/ijfr.v6n2p23

Yang, Z., Ali, S.T., Ali, F., Sarwar, Z., \& Khan, M.A. (2020). Outward foreign direct investment and corporate green innovation: An institutional pressure perspective. South African Journal of Business Management, 51(1), a1883. https://doi. org/10.4102/sajbm.v51i1.1883

Zhong, R.I. (2018). Transparency and firm innovation. Journal of Accounting and Economics, 66(1), 67-93. https://doi.org/10.1016/j.jacceco.2018.02.001

Zhou, K.Z., Gao, G.Y., \& Zhao, H. (2017). State ownership and firm innovation in China: An integrated view of institutional and efficiency logics. Administrative Science Quarterly, 62(2), 375-404. https://doi.org/10.1177/0001839216674457 